\title{
Kemampuan Komunikasi Matematik Siswa Berdasarkan Gender: Suatu Kasus di Sekolah Berbasis Pesantren
}

\author{
Wa Ode Dahiana*, Tatang Herman \\ Universitas Pendidikan Indonesia, Indonesia \\ *wdiana@upi.edu \\ C 2021 JIPM (Jurnal Ilmiah Pendidikan Matematika)
}

This is an open access article under the CC-BY-SA license (https://creativecommons.org/licenses/bysa/4.0/) ISSN 2337-9049 (print), ISSN 2502-4671 (online)

\begin{abstract}
Abstrak:Tujuan penelitian ini untuk mengetahui perbedaan kemampuan komunikasi matematis siswa berdasarkan gender dengan pembelajaran yang menggunakan strategi metakognitif. Metode penelitian ini adalah kuasi eksperimen yang menggunakan desain pretest-posttest control groupdesign. Teknik pengambilan sampel yang digunakan adalah Sampling Jenuh yang terdiri dari dari 19 siswa laki-laki sebagai kelompok eksperimen pertama dan 17 perempuan sebagai kelompok eksperimen kedua. Instrumen yang digunakan berupa tes uraian berjumlah lima butir untuk mengukur aspek kemampuan komunikasi matematik siswa setelah diberikan treatmen yakni pembelajaran yang menggunakan strategi metakognitif. Nilai rata-rata pre-test memperlihatkan siswa perempuan lebih tinggi daripada laki-laki, sebaliknya, nilai rata-rata hasil post-test, diketahui siswa laki-laki lebih tinggi. Data selanjutnaya dianalisis dengan menggunakan uji $t$, diperoleh kesimpulan bahwa ada perbedaan yang signifikan antara kemampuan matematik siswa laki-laki dan perempuan. Perbedaan ini konsisten dengan sejumlah hasil penelitian sebelumnya, walaupun tidak sedikit juga hasil penelitian menyatakan tidak ada perbedaan yang signifikan antara kemampuan akademik siswa berdasarkan gender.
\end{abstract}

Kata kunci: Kemampuan Komunikasi Matematik; Gender; strategi metakognitif; pesantren

Abstract: The purpose of this study was to determine differences in students' mathematical communication skills based on gender with learning using metacognitive strategies. This research method is a quasi-experimental design using a pretest-posttest control group design. The sampling technique used was saturated sampling which consisted of 19 male students as the first experimental group and 17 female students as the second experimental group. The instrument used was in the form of a five-point essay test to measure the aspects of students' mathematical communication skills after being given a treatment, namely learning using metacognitive strategies. The pre-test mean score shows that female students are higher than male students, on the contrary, the average score of the post-test results, it is known that male students are higher. The data were analyzed using the t-test, it was concluded that there was a significant difference between the mathematical abilities of male and female students. This difference is consistent with several previous research results, although not a few studies also state that there is no significant difference between students' academic abilities based on gender.

Keywords: Mathematical Communication Skills; Gender; metacognitive strategies; boarding school. 
Wa Ode Dahiana, Tatang Herman

\section{Pendahuluan}

Berbagai Penelitian tentang gender sudah banyak dilakukan di berbagai Negara dengan berbagai tema dan disiplin ilmu. Mulai dari masalah kepribadian (Fallan \& Opstad, 2016), bidang Ekonomi, Bahasa dan linguistic (Setati, 2002; Guiller \& Durndell, 2007; Bishop, 2008), masalah sains, teknologi informasi dan komunikasi (TIK), matematika (Ma, 1999; Gallagher, \& Frontmatter, 2005; Lindberg et al., 2010) dan sebagainya.

Di bidang matematikapun beragam topik, baik kemampuan matematik secara umum maupun kemampuan matematik secara khusus seperti komunikasi matematik (Steinbring, 2009; Santos \& Semana, 2015; Zakiri \& Pujiastuti, 2018) kemampuan penalaran, teknologi informasi dan komunikasi dan pencapaian matematik (Meggiolaro, 2018), Kecemasan Matematika (Bowd \& Brady, 2003), matematika self efficacy (Goodwin, Ostrom \& Scott, 2009). Dari berbagai penelitian yang dilakukan tersebut menghasilkan beragam kesimpulan. Seperti yang dikatakan Meggiolaro (2018) bahwa kesimpulan yang diambil tentang perbedaan gender dalam matematika sangat bervariasi, tergantung pada beberapa faktor, antara lain factor usia. Selain factor usia, menurut Ma (1999) factor karakteristik tingkat sekolah juga berpengaruh. Demikian juga factor kognitif, sosial, kepribadian / orientasi diri, dan psikobiologis, sosiologis, etnis dan budaya dan sebagainya (Gallagher, \& Frontmatter, 2005).

Terkait faktor kognitif, beberapa penelitian menunjukkan adanya perbedaan fisik antara otak pria dan perempuan dalam struktur dan fisiologis (Triyadi, 2013). Oleh karena itu, perbedaan kemampuan otak laki-laki dan perempuan juga dapat mempengaruhi proses pembelajaran di kelas. Hal ini pula yang menjadikan isu gender menjadi perbincangan dan diskusi berdasarkan pengalaman sosial yang dinamis yang meliputi pengalaman pendidikan di dalam dan luar sekolah ( Zakiri, Pujiastuti \& Noor, 2018).

Wigfield et al. (2002) menyatakan bahwa bertahun-tahun eksplorasi perbedaan gender dalam prestasi matematika telah dilakukan, hasilnya menunjukkan bahwa anak laki-laki mengungguli perempuan. Statemen ini juga didukung oleh Kimball (1989) bahwa banyak penelitian yang menunjukkan anak laki-laki di kelas sekolah atas pada umumnya mencapai skor lebih tinggi daripada anak perempuan. Selanjutnya, studi perbedaan gender oleh Peterson \& Fennema (1985); Randhawa (1994); Hedges \& Nowell (1995) menemukan bahwa secara umum, laki-laki mengungguli perempuan dalam matematika. Demikian juga Fox, Brody \& Tobin (1980) menyatakan bahwa prestasi matematika yang tinggi didominasi oleh laki-laki. Asante (2010) juga telah melaporkan adanya perbedaan gender dalam mata pelajaran sains, secara umum, juga seperti dalam matematika. Penelitian tentang kecemasan dan kepribadian disimpulkan bahwa anak laki-laki memiliki kecemasan matematika yang lebih rendah, dan memiliki persepsi kemampuan matematika lebih tinggi daripada anak perempuan (Randhawa, 1994). Sedangkan perempuan secara konsisten mendapatkan skor kecemasan matematika lebih tinggi (Bowd \& Brady, 2003). Namun hasil penelitian tersebut telah terbantahkan oleh beberapa penelitian selanjutnya. Mereka menemukan bahwa Laki-laki dan perempuan memperoleh keterampilan matematika pada tingkat yang sama (Ma, 1999). Anak perempuan tampil lebih baik daripada anak laki-laki dalam perhitungan di sekolah dasar dan sekolah menengah tetapi perbedaannya sangat kecil. Ditemukan juga bahwa tidak ada perbedaan gender dalam hal kinerja di sekolah menengah (Lindberg et al., 2010).

Di sisi lain, reformasi dalam pendidikan matematika telah mengundang guru untuk menciptakan lingkungan pembelajaran yang mendorong perkembangan intelektual siswa (Fennema \& Franke, 1992). Lingkungan pembelajaran harus memungkinkan peserta didik 
mengeksplorasi ide-ide matematika, memperdalam pemahaman mereka tentang ide-ide ini, dan membuat koneksi matematis dalam dan di luar matematika (NCTM 1991; Brown \& Borko, 1992). Inti dari bentuk kegiatan seperti ini adalah berbagai bentuk komunikasi, baik lisan maupun tulisan, yang memungkinkan peserta didik untuk terlibat dengan teman sebaya dan guru dalam membentuk pengetahuan matematika yang kaya (Brendefur \& Frykholm, 2000). Hal ini menandakan bahwa dalam mengembangkan ide dan pengetahuan serta pemahaman matematik, tidak bisa dipungkiri peran komunikasi sangat dibutuhkan.

Menurut Ramdani (2012), dan Sefiany, Masrukan \& Zaenuri (2016) bahwa kemampuan berkomunikasi mencakup kemampuan menyampaikan konsep atau ide matematika baik secara lisan atau tulisan. Kemampuan ini dapat dimiliki melalui aktivitas mengamati, meninjau, menafsirkan, dan mengevaluasi ide, simbol, terminologi, dan informasi matematika yang dibutuhkan. Hal ini mengisyaratkan bahwa semua aktivitas di kelas matematik menuntut siswa untuk memiliki kemampuan komunikasi matematik. Dengan kata lain kemampuan komunikasi merupakan jantung dari pengalaman kelas yang merangsang pembelajaran. Senada dengan ini, Dewan Nasional Guru Matematika (NCTM, 2000, p. 60) menyatakan bahwa komunikasi adalah bagian penting dari matematika dan pendidikan matematika. Komunikasi juga merupakan satu dari lima standar proses yang ditekankan oleh NCTM. Standar komunikasi menyoroti pentingnya siswa mengkomunikasikan pemikiran matematika mereka secara koheren dengan teman sebaya dan guru. Siswa harus menggunakan bahasa matematika untuk mengekspresikan ide-ide matematika (Coocke \& Buchholz, 2005). Seorang siswa yang tidak bisa berkomunikasi dengan benar, menafsirkan konsep dan kemampuan lainnya dalam matematik niscaya mereka tidak akan bisa menyelesaikan masalah dengan benar pula (Alhaddad et al., 2015).

Meskipun kemampuan komunikasi itu penting untuk dikuasai siswa namun kenyataan di lapangan kemampuan tersebut belum memuaskan. Hal ini dapat dilihat dari hasil yang diperoleh siswa Indonesia di ajang TIMSS tahun 2007, bahwa siswa Indonesia masih lemah dalam hal komunikasi matematis. Ini dapat dilihat misalnya pada soal tentang membaca data dalam diagram lingkaran dan menyajikannya dalam bentuk diagram batang. Diketahui hanya $14 \%$ siswa peserta Indonesia yang dapat menjawab dengan benar, sedangkan di tingkat internasional terdapat $27 \%$ siswa yang menjawab benar (Satriawati dalam Dahiana, Herman \& Nirawati, 2020).

Demikian pentingnya kemampuan komunikasi matematik yang harus dikuasai oleh siswa, berbagai upayapun telah dilakukan. Penelitian Nerru, Mariani \& Cahyono (2013) menggunakan pembelajaran Metode Reciprocal Teaching Berbantuan Cabri untuk meningkatkan komunikasi matematik siswa kelas X, hasilnya berupa perangkat yang valid untuk digunakan sebagai alternative dalam pembelajaran di kelas. Pasaribu, Siagian \& Amry (2018) untuk meingkatkan komunikasi matematik siswa digunakan strategi Problem Based Learning (PBL) dan Pendidikan Matematika Realistis (PMR). Penelitian ini merupakan eksperimen semu yang dilakukan di kelas VIII, hasil penelitian menunjukkan bahwa ada perbedaan dalam meningkatkan komunikasi dan disposisi matematis siswa melalui PBL dengan PMR.

Tandililing (2011) menggunakan strategi PQ4R (Preview, Question, Read, Reflect, Recite, Review) dan masih banyak lagi strategi ataupun pendekatan pembelajaran lainnya yang digunakan dalam rangka upaya meningkatkan kemampuan komunikasi matematik siswa. Secara khusus penelitian lain untuk meningkatkan kemampuan komunikasi matematik sekaligus mengkaji perbedaan gender yakni dengan menggunakan model Problem Based Learning (PBL) oleh Zakiri, Pujiastuti \& Noor (2018). Hasil penelitian ini menunjukkan $\mathrm{H}_{0}$ 
diterima, artinya tidak ada perbedaan kemampuan komunikasi matematis siswa pria dan wanita yang menggunakan model PBL.

Dalam penelitian ini, untuk mengetahui kemamapuan komunikasi matematik siswa, serta pengaruh (hubungan) nya dengan gender, peneliti menggunakan strategi metakognitif pada siswa kelas VII di salah satu sekolah (pesantren) di Jawa Barat. Adapun indikator kemampuan komunikasi (untuk pots-test) yang digunakan dalam penelitian ini yakni menurut Hendrian, Rohaeti \& Sumarmo (2018) seperti berikut: (1) Menyatakan peristiwa sehari-hari ke dalam bahasa atau simbol matematika dan menyelesaikannya, (2) Menggunakan kemampuan menginterpretasi dari model matematika ke dalam peristiwa nyata (sehari-hari), (3) Mengilustrasikan ide dan permasalahan yang diberikan ke dalam model matematika dan menyelesaikannya. Penelitian ini melibatkan gender sebagai salah satu variable yang dikaji dan hasilnya menunjukkan bahwa ada perbedaan capaian hasil tes akhir (post-test) yang ditunjukkan dengan nilai rerata (mean) siswa laki-laki lebih besar daripada perempuan.

Pesantren ini dipilih sebagai lokasi penelitian karena merupakan sekolah baru yang sudah tentu belum banyak diterapkan model-model, ataupun strategi pembelajaran yang dapat meningkatkan kemampuan matematik siswa. Selain itu, kurikulum dan program pembelajaran dipesantren berbeda dengan sekolah pada umumnya. Ada Pesantren yang menerapakan kurikulum nasional juga ditambah dengan kurikulum pesantren sendiri dan ada juga pesantren yang hanya menggunakan kurikulum sendiri. Pada pesantren yang kami gunakan ini adalah pesantren yang menggunakan kurikulum nasional dan dipadu dengan kurikulum sendiri. Santri (siswa) menetap di asrama (rumah) yang disediakan untuk tempat tinggal santri yang terpisah antara santri laki-laki dan perempuan, demikian juga ruang kelas untuk belajar mereka. Adapun sistem pembelajarannya yakni 24 jam, mulai pagi jam 07.00 sampai jam 14.00 belajar dikelas seperti sekolah umumnya dan pada malam hari mulai jam 19.00 belajar materi agama dan praktek-praktek keterampilan lainnya misalnya, membaca kitab suci, melaksanakan ibadah sholat, ceramah, dan lain-lain. Mengenai kondisi santri (siswa) di pesantren ini memiliki latar belakang kehidupan sosial dan budaya (bahasa daerah, kebiasaan, dan lain-lain) yang berbedabeda. Salah satu hal yang paling menonjol dalam interaksi di pesantren adalah perbedaan bahasa juga dialek. Yakni bahasa yang digunakan baik dalam pembelajaran di kelas maupun dalam interaksi sosial di asrama. Di kelas, terkadang guru menggunakan bahasa daerah setempat yang tentu menyebabkan sebagian siswa kurang memahami apa yang disampaikan oleh guru tersebut. Hal ini tentu membutuhkan waktu bagi sebagian santri untuk beradaptasi baik untuk belajar di kelas maupun dalam interaksi sosial sehari-hari di tempat tinggal (asrama). Penyebutan santri maksudnya adalah siswa, untuk siswa laki-laki disebut dengan santriawan sedangkan siswa perempuan disebut dengan santriwati (Setiawan, 2013). Dalam tulisan ini selanjutnya digunakan penyebutan umum yakni siswa laki-laki dan perempuan.

Strategi metakognitif dipilih dalam penelitian ini karena strategi ini dapat memberikan kemampuan konsep matematik siswa lebih baik (Jbeili, 2012). Metakognisi membantu siswa untuk mengenali bahwa matematika adalah penalaran logis pada solusi untuk masalah (Su, Ricci \& Mnatsakanian, 2016). Metakognitif merupakan pengetahuan tentang proses berpikir seseorang (Schoenfeld, 992 dan Hacker, 1998). Metakognisi adalah pengetahuan kognisi siswa yang melibatkan kesadaran pemikiran mereka sendiri dalam hal kemampuan perencanaan, pemantauan dan proses evaluasi pemikiran (Sholihah, 2016). Marzano and Association for Supervision and Curriculum Development (1988) membagi metakognisi ke dalam dua aspek 
utama yaitu (1) Pengetahuan dan kontrol diri (knowledge and control of self) dan (2) Pengetahuan dan kontrol proses. (knowledge and control of process).

Selanjutnya, Laurens (2014) menyatakan bahwa pemanfaatan metakognisi dapat membantu menyelesaikan masalah dalam matematika termasuk pembelajaran matematika. Demikian juga hasil penelitian Su, Ricci \& Mnatsakanian (2016) bahwa metakognisi didasari keterampilan berpikir kritis. Siswa yang memiliki kemampuan berpikir kritis yang semakin tajam akan semakin baik dalam memecahkan masalah matematika dimana mereka mampu memformulasikan pendapat-pendapatnya berdasarkan pengetahuan luas yang dimilikinya. Pengetahuan luas yang dimaksud terkait dengan metakognisi yang dimilikinya.

Beberapa manfaat keterampilan metakognitif menurut para ahli juga dikemukakan oleh Corebima sebagai berikut:

1. Eggen dan Kauchak (1996) menyatakan bahwa pengembangan kecakapan metakognitif siswa adalah suatu tujuan pendidikan yang berharga, karena kecakapan itu dapat membantu mereka menjadi self-regulated learners. Self-regulated learners bertanggung jawab terhadap kemajuan belajarnya sendiri dan mengadaptasi strategi belajarnya mencapai tuntutan tugas.

2. Marzano (1988), manfaat metakognisi (strategi) bagi guru dan siswa adalah menekankan monitoring diri (kecakapan berpikir tinggi) dan tanggung jawab.

3. Howard (2004) menyatakan bahwa keterampilan metakognitif diyakini memegang peranan penting pada banyak tipe aktivitas kognitif termasuk pemahaman, komunikasi, perhatian (attention), ingatan (memory), dan pemecahan masalah.

4. Peters (2000) berpendapat bahwa keterampilan metakognitif memungkinkan para siswa berkembang sebagai pebelajar mandiri, karena mendorong mereka menjadi manajer atas dirinya sendiri serta menjadi penilai atas pemikiran dan pembelajarannya sendiri.

Berdasarkan manfaat keterampilan metakognitif yang telah diuraikan di atas, sangatlah penting untuk menerapkan strategi metakognitif dalam pembelajaran di kelas untuk membantu siswa menyelesaikan tugas belajarnya dengan baik. Selain itu, perlu juga diadakan studi (penelitian) tentang metakognitif untuk memberikan informasi yang luas dan ilmiah baik kepada guru maupun pemerhati bidang pendidikan matematika atas berbagai permasalahan pembelajaran yang dialami siswa. Dalam temuan penelitian ini yang berbeda dari temuan sebelumnya adalah pada hasil pre-test yang menggunkan soal-soal komputasi sederhana, siswa perempuam memperoleh nilai rerata (mean) yang lebih besar daripada siswa laki-laki. Namun setelah diberikan perlakuan, yakni pembelajaran dengan menggunkan strategi metakognitif, hasil post-test dalam hal ini nilai rerata yang lebih besar dicapai oleh siswa laki-laki. Hal ini disebabkan karena strategi metakognitif lebih memungkinkan anak laki-laki untuk mengembangkan berpikir penalaran logis dan berpikir logis. Hasil ini konsisten dengan temuan Jbeili (2012) bahwa siswa laki-laki yang belajar menggunakan pembelajaran kooperatif dengan metakognitif secara signifikan mengungguli siswa yang menggunakan model pembelajaran lainnya.

Strategi metakognitif adalah teknik yang digunakan pembelajar dalam merencanakan, memantau dan mengendalikan, serta mengevaluasi proses kognitif mereka sendiri (Woolfolk, 2007). Veenman, Wilhelm \& Beishuizen (2004) menyarankan strategi metakognitif yang diajarkan untuk memungkinkan peserta didik untuk belajar bersama untuk memahami konsep yang dipelajari. Demikian juga Kramarski \& Mizrach (2006) menegaskan bahwa pembelajar yang sukses bertanya pada diri sendiri. Beberapa Pertanyaan metakognitif yang perlu dimunculkan 
pembelajara sebelum (melalui perencanaan), selama (melalui pemantauan), dan setelah (melalui evaluasi) tugas belajar. Misalnya:

\section{Pada tahap perencanaan:}

1. Apakah saya memiliki pengetahuan sebelumnya tentang materi, topik atau masalah ini ?

2. Apa yang harus saya lakukan lebih dahulu?

3. Tahukah saya di mana bisa mendapatkan informasi tentang topik ini?

4. Berapa lama waktu yang dibutuhkan untuk mengetahuinya?

5. Strategi apa saja yang dapat saya gunakan untuk belajar ini?

\section{Pada tahap pemantauan:}

1. Apakah saya mengerti apa yang baru saya dengar, baca atau lihat?

2. Apakah saya berada pada posisi (pemahaman) yang benar?

3. Bagaimana saya bisa melihat (mengetahui) kesalahan jika saya mengerjakan sesuatu?

4. Bagaimana saya harus merevisi rencana saya jika tidak berfungsi?

5. Apakah saya perlu menjaga atau membuat catatan yang bagus?

\section{Pada tahap evaluasi:}

1. Apakah saya memiliki strategi tertentu untuk menghasilkan apa yang saya harapkan?

2. Apa yang bisa saya miliki untuk melakukan yang berbeda?

3. Bagaimana saya bisa menerapkan pemikiran ini ke masalah yang lain?

Berdasarkan penjelasan tentang pengertian strategi metakognisi di atas dapat disimpulkan bahwa strategi metakognisi adalah teknik yang digunakan pembelajar untuk memonitor proses berpikirnya pada saat sebelum, sedang, dan sesudah pembelajaran dilaksanakan. Pengajar (guru) memberika kesempatan kepada peserta didik untuk bertanya kepada diri sendiri selama proses pembelajaran berlangsung agar mereka terbiasa memantau proses kognitifnya. Pembelajaran dilakukan dalam bentuk kelompok sehingga memudahakan guru mengkordinir aktivitas kelas. Adapun materi yang didiskusikan dalam kajian ini adalah materi aljabar. Penelitian ini bertujuan untuk memberikan wawasan tentang perbedaan capaian hasil belajar antara siswa laki-laki dan perempuan terhadap aspek kemampuan komunikasi matematik dengan menggunkan strategi metakognitif pada salah satu pesantren di Provinsi Jawa Barat, Indonesia.

\section{Metode}

Partisipan

Partisipan terdiri dari 36 siswa kelas VII yang terdiri dari 19 siswa laki-laki sebagi kelompok eksperimen pertama dan 17 perempuan sebagai kelompok eksperimen kedua (Ruseffendi, 1993). Penelitian ini dilakukan tahun ajaran 2018/2019 semester genap di sebuah pesantren di daerah Jawa Barat. Usia santri rata-rata 13 sampai 14 tahun. Santri (siswa) yang belajar pada pesantren ini berasal dari berbagai wilayah di indonesia yang notabene memiliki beragam latar belakang sosial dan budaya. Pesantren ini juga merupakan pesantren baru yang memiliki jumlah siswa relatif sedikit. Adapun guru yang mengajar di pesantren ini berasal dari berbagai kalangan dan belum ada yang bersatus sebagai pegawai negeri sipil (PNS). Sebagian besar mereka adalah mahasiswa tingkat akhir dan beberapa juga merupakan tenaga honorer yang sudah mengabdi diberbagai lembaga pendidikan (sekolah). Sebelumnya, di pesantren ini 
belum ada yang melakukan penelitian, karena merupakan pesantren yang tergolong masih baru dan belum dikenal luas oleh khalayak.

Prosedur

Penelitian ini menggunakan metode kuantitatif untuk mengukur kemampuan komunikasi matematik siswa. Jenis penelitian adalah kuasi eksperimen dengan desain Nonrandomized Pre-test Post-test Control Group Design. Teknik pengambilan sampel yang digunakan adalah sampling jenuh (semua populasi dijadikan sampel) karena ukurannya yang relative kecil. Kedua kelas (laki-laki dan perempuan) mendapatkan pendekatan pembelajaran yang sama yakni strategi metakognitif. Oleh karena kedua kelas sama-sama menggunakan pembelajaran yang baru (bukan konvensional) sehingga kedua kelas sama-sama merupakan kelas eksperimen yang dalam penelitian ini kelas laki-laki ditempatkan sebagai kelas eksperimen pertama dan kelas perempuan sebagai kelas eksperimen kedua (Ruseffendi, 1993).

Terdapat delapan langkah atau tahapan strategi metakognitif dalam penelitian ini yang dapat digambarkan dalam bentuk diagram berikut.

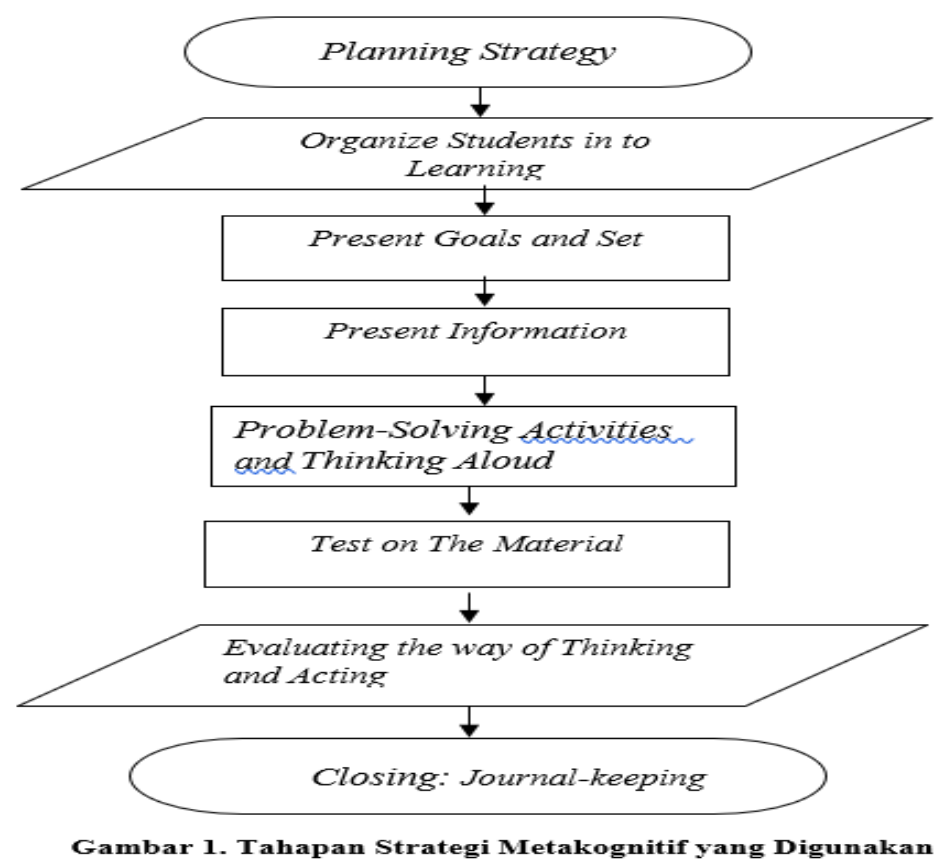

Langkah-langkah stategi metakognitif di atas dapat dijelaskan sebagai berikut: (1) Tahap awal: planning strategy (Strategi perencanaan); membuat kesepakatan tentang aturan dan strategi pembelajaran yang akan dilaksanakan, (2) Organize students in to learning teams (mengorganisasi siswa dalam kelompok belajar); mengkondisikan siswa dalam kelompokkelompok kecil dan heterogen, (3) Present goals and set (menyampaikan/menetapkan tujuan dan mempersiapkan peserta didik), (4) Present information (penyajian informasi), menyajikan konsep/materi pemebelajaran secara verbal kemudian membagikan lembar kegiatan siswa, (5) Problem-solving activities and Thinking aloud (kegiatan pemecahan masalah dan berpikir keras); membimbing siswa untuk mengajukan pertanyaan metakognitif dan memotivasi siswa untuk terlibat aktif, berpikir keras dalam proses pemecahan masalah, (6) Test on the material; siswa 
mempresentasikan hasil kerja kelompok, pengajar menilai tingkat penguasaan siswa secara kelompok dan secar individu dengan memberikan soal tes terhadap materi pembelajaran yang sudah diajarkan, (7) Evaluating the way of thinking and acting (mengevaluasi cara berpikir dan bertindak); siswa menilai pemikiran mereka sendiri dan menilai kegiatan pembelajaran dan (8) Journal-keeping (Penyimpanan jurnal); sebagai penutup, siswa membuat buku harian pribadi untuk menuliskan ekspresi pikiran dan tindakan sepanjang pengalaman belajar terjadi di kelas.

\section{Teknik Pengumpulan Data}

Teknik pengumpulan data dalam penelitian ini dilakukan dengan teknik tes yang diberikan sebanyak dua kali yakni sebelum diberikan perlakuan (pre-test) dan sesudah diberikan perlakuan (post-test). Pres-Test (tes awal) diberikan untuk mengetahui kemampuan awal mereka mengenai materi ajabar. Instrument tes awal berjumlah empat soal tes bentuk uraian, materi aljabar yang menuntut aktivitas kognisi (aktivitas mental) yang relatif sederhana dengan indikator soal yakni: (1) Menentukan variable, koefisien dan konstanta, (2) Menyederhanakan bentuk aljabar, (3) Menginterpretasi model matematika ke dalam peristiwa nyata (sehari-hari). Sedangkan instrument tes akhir berjumlah 5 butir soal uraian. Tes akhir ini menuntut aktivitas kognitif yang lebih tinggi dengan indikator soal yakni: (1) Menyatakan peristiwa sehari-hari ke dalam bahasa atau simbol matematika dan menyelesaikannya, (2) Menggunakan kemampuan menginterpretasi dari model matematika ke dalam peristiwa nyata (sehari-hari), (3) Mengilustrasikan ide dan permasalahan yang diberikan ke dalam model matematika dan menyelesaikannya. Adapun instrument lain (non tes) tidak dianalisis lebih lanjut, yakni lembar pengamatan diri yang digunakan siswa untuk memantau aktivitas metakognisi mereka sendiri selama proses pembelajarn di kelas. Lembar pengamatan diri yang dimaksud memuat komponen berupa, hari/tanggal, nama/kleas, topik/sub topi materi, bagian-bagian yang sudah dipahami, kesulitan/bagian-bagian yang belum dipahami, Strategi/cara belajar utk menguasai materi, dan keterangan.

\section{Teknik Analisi Data}

Jenis data dalam penelitian ini adalah data kuantitatif yang diperoleh dari hasil pre-test dan post-test. Sesuai dengan tujuan penelitian yakni untuk mengetahui ada tidaknya perbedaan kemampuan komunikasi matematik antara siswa laki-laki dan perempuan, selanjutnya data dalam penelitian ini dianalisis dengan menggunakan uji beda rata-rata (uji-t dua sampel bebas). Perhitungan dilakukan dengan menggunakan Microsoft Office Excel dan Software SPSS 20.0

\section{Hasil dan Pembahasan}

Hasil Pre-test

Hasil pre-test (kemampuan awal) siswa laki-laki dan perempuan disajikan pada tabel 1, menampilkan statistik deskriptif dan nilai t-test sampel independen dari nilai pre-test siswa yang berpartisipasi dalam penelitian ini.

Table 1. Means, standard deviations and independent samples t-test values of pre-test scores of groups of male and female students

\begin{tabular}{|l|l|l|l|l|l|l}
\hline Group & N & Mean & SD & Df & t-value & p-value
\end{tabular}




\begin{tabular}{|l|l|l|l|l|l|l|}
\hline Male & 19 & 29.79 & 23.437 & 34 & -2.478 & 0.018 \\
\cline { 1 - 4 } Female & 17 & 51.29 & 28.602 & & & \\
\hline
\end{tabular}

Analisis data pre-test memperlihatkan adanya perbedaan nilai mean untuk laki-laki dan perempuan yakni anak perempuan lebih besar nilai mean nya daripada laki-laki demikian juga p-value terdapat perbedaan yang cukup signifikan. Untuk diketahui bahwa instrument tes awal menampilkan soal-soal aljabar yang sederhana yakni menuntut kemampuan komputasi. Temuan ini juga konsisten dengan temuan penelitian sebelumnya yakni Lindberg et al. (2010); Meggiolaro (2018); dan Hyde, Fennema \& Lamon (1990) yang menyatakan bahwa anak perempuan unggul dalam mata pelajaran matematika (aljabar) yang hanya membutuhkan proses kognitif yang relatif sederhana, dalam kegiatan yang melibatkan penggunaan rumus, dan komputasi. Hal ini disebabkan anak perempuan lebih teliti dan hati-hati dalam hal perhitungan.

\section{Hasil Post-test}

Hasil post-test (tes kemampuan komunikasi matematik) siswa laki-laki dan perempuan disajikan pada tabel 2, menampilkan statistik deskriptif dan statistic inferensi dari partisipan yang terlibat dalam penelitian ini.

Table 2. Means, standard deviations and independent samples t-test values of post-test scores of groups of male and female students

\begin{tabular}{|l|l|l|l|l|l|l|}
\hline Group & $\mathrm{N}$ & Mean & SD & Df & t-value & p-value \\
\hline Male & 19 & 44.63 & 19.794 & 34 & 4.715 & 0.000 \\
\cline { 1 - 3 } & 17 & 20.29 & 8.199 & & & \\
\hline
\end{tabular}

Secara grafik nilai rerata (mean) hasil pre-test dan post-test dapat ditampilkan seperti berikut.

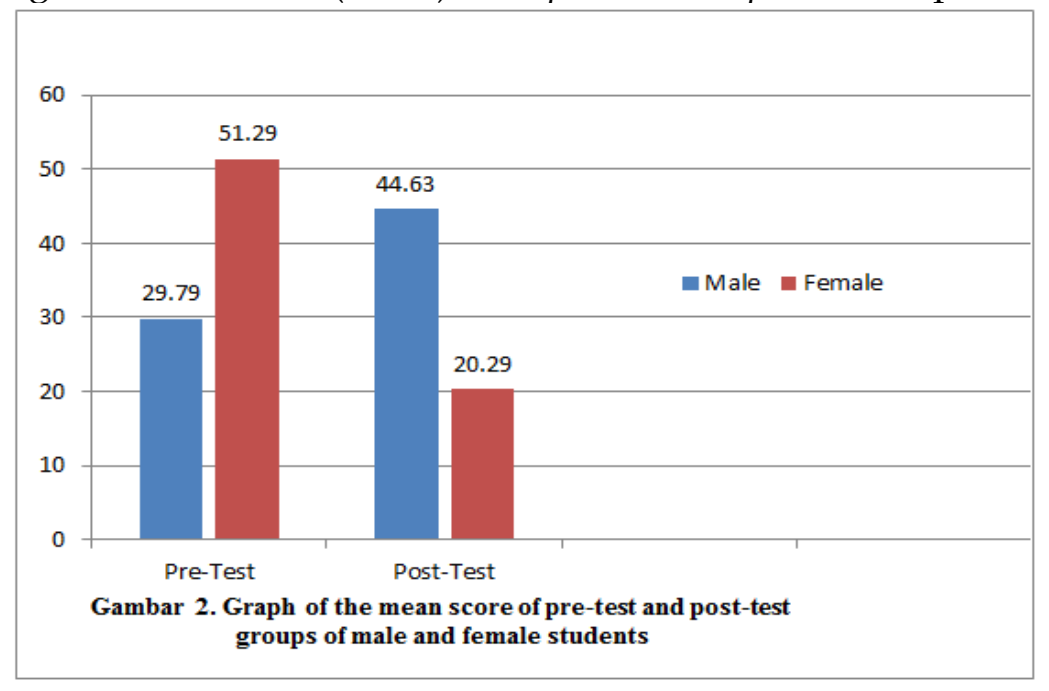

Hasil analisis data post-test memberikan informasi yang berbeda. Berdasarkan nilai mean maupun $P$-value menandakan bahwa kemampuan yang dimiliki anak laki-laki setelah diberikan treatmen berupa pembelajaran dengan menggunakan strategi metakognitif hasilnya meningkat lebih besar dibanding dengan anak perempuan. Untuk diketahui pula bahwa soal post-test yang 
diberikan yakni soal-soal untuk mengukur kemampuan komunikasi matematik, yang membutuhkan penalaran bukan sekedar komputasi biasa sebagaimana soal-soal yang diberikan pada saat pre-test. Hasil ini konsisten juga dengan temuan penelitian sebelumnya bahwa Anak laki-laki berkinerja lebih baik daripada anak perempuan pada pada tugas-tugas yang menilai penalaran dan kemampuan pemecahan masalah (Meggiolaro, 2018). Demikian juga temuan Anastasi (dalam Lindberg et al., 2010) bahwa superioritas pria muncul untuk tes yang membutuhkan pemrosesan kognitif yang lebih maju, seperti pemecahan masalah yang kompleks. Perbedaan gender dalam kinerja matematik sangat beragam karena dalam berbagai tugas membutuhkan keterampilan matematika yang berbeda. Secara umum, kinerja pria lebih unggul daripada kinerja wanita dalam tugas yang melibatkan estimasi logis, strategi solusi berganda, ekstraksi informasi dan item berdasarkan pada kombinasi keterampilan pemahaman konseptual. Sedangkan perempuan lebih efektif dalam tugas yang memerlukan strategi algoritmik rutin dan bacaan luas atau penjelasan (Meggiolaro, 2018).

Kemungkinan lain yang menyebabkan kemampuan anak laki-laki lebih unggul dalam studi ini adalah karena pembelajaran yang diberikan yakni strategi metakognitif lebih memungkinkan anak laki-laki untuk mengembangkan berpikir penalaran logis dan berpikir logis. Seperti temuan Jbeili (2012) bahwa siswa laki-laki yang belajar dengan menggunakan pembelajaran kooperatif dengan metakognitif secara signifikan mengungguli siswa dalam kelompok koperatif tanpa metakognitif. Demikian juga pendapat Su, Ricci \& Mnatsakanian (2016) bahwa metakognisi membantu siswa untuk mengenali matematika sebagai penalaran logis pada solusi untuk masalah.

Meskipun dalam beberapa penelitian termasuk dalam hal menggunakan strategi metakognitif tidak terdapat perbedaan yang signifikan antara siswa laki-laki dan perempuan namun dalam penelitian ini terlihat adanya perbedaan bahkan cukup signifikan. Banyak temuan penelitian menyangkut perbedaan gender dalam metakognisi tidak pasti atau tidak konsisten (Liliana \& Lavinia, 2011). Ketidakkonsistenan ini dijelaskan pula oleh Ormrod (2008, p. 372) bahwa faktor usia mempengaruhi perkembangan karakteristik metakognisi anak. Untuk usia SMP (sederajat), fleksibilitas penggunaan strategi belajar meningkat yakni pemantauan pemahaman belum efektif, juga keyakinan dan kesadaran terhadap pengetahuan pun baru mulai berkembang. Berkaitan dengan keyakinan diri, Virtanen \& Nevgi (dalam Liliana \& Lavinia, 2011) dalam temuan penelitiannya dijelaskan bahwa untuk kasus anak perempuan, persepsi diri mereka cenderung rendah dalam bidang matematika dan sains dan mencapai puncaknya selama usia remaja. Dengan kata lain, anak laki-laki lebih percaya diri dalam hal motivasi untuk belajar.

Temuan lainnya juga dinyatakan bahwa dalam pemecahan masalah matematika beberapa literatur umumnya mendukung siswa laki-laki namun generalisasi semacam itu tidak dimungkinkan (Demirel, Derman \& Karagedik, 2015). Artinya, bahwa generalisasi yang mendukung anak laki-laki lebih unggul dari perempuan ataupun sebaliknya tidaklah berlaku dalam semua kondisi dan tempat.

Demikian juga dalam temuan penelitian ini yang mendukung siswa laki-laki lebih unggul (hasil post-test) maupun siswa perempuan lebih unggul dilihat dari hasil pre test, hanya bisa digeneralisasi pada lokasi yang dijadikan obyek penelitian ini. Dalam kasus ini, dapat penulis jelaskan bahwa subyek penelitian ini, berasal dari berbagai daerah di indonesia yang memiliki latar belakang dan budaya yang berbeda-beda, serta berasal dari sekolah yang sebelumnya tidak memperhatikan gender di dalam penempatan ruang kelas. Mereka kurang dari setahun berada pada situasi seperti demikian (terpisah ruang kelas antara laki-laki dan perempuan) serta tempat 
tinggal yang baru bagi mereka yang terpisah dari orang tua mereka karena tinggal di asrama. Hal ini tentunya membutuhkan waktu atas berbagai hal yang harus mereka adaptasi dengannya. Kondisi ini didukung juga oleh klaim dari Fennema dan Sherman (dalam Asante, 2010) bahwa perbedaan dalam prestasi matematika bisa dimungkinkan karena pengaruh atau faktor sosial.

\section{Simpulan dan Saran}

Terdapat perbedaan pencapaian kinerja matematik siswa (kemampuan komunikasi matematik) berdasarkan gender pada level (keterampilan) kognitif yang berbeda. Untuk memahami perbedaan gender terkait dengan kemampuan komunkasi matematik lebih lanjut, disarankan sebaiknya dilakukan studi dengan memperhatikan berbagai faktor yang mempengaruhi (misalnya sosial dan budaya). Selain itu, perlu juga melibatkan jumlah partisipan yang lebih besar (untuk penelitian kuantitatif). Untuk dapat memahami lebih mendalam tentang perbedaan ataupun karakteristik gender perlu digunakan penelitian dengan metode kualitatif.

\section{Daftar Rujukan}

Alhaddad, I., Kusumah, Y. S., Sabandar, J., \& Dahlan, J. A. (2015). Enhancing Students' Communication Skills Through Treffinger Teaching Model. Journal on Mathematics Education, 6(1), 31-39. https://doi.org/10.22342/jme.6.1.1856.31-39

Asante, K. (2010). Sex Differences in Mathematics Performance among Senior High Students in Ghana. Gender and Behaviour, 8(2), 3279-3289. https:// doi.org/10.4314/gab.v8i2.61947

Bishop, A. J. (2008). Mathematics Education Library of Congress Control Number: 2007936207. Springer Science+Business Media, LLC.

Bowd, A. D., \& Brady, P. H. (2003). Gender Differences in Mathematics Anxiety Among Preservice Teachers and Perceptions of Their Elementary and Secondary School Experience with Mathematics. XLIX, No. 1, 24-36.

Brendefur, J., \& Frykholm, J. (2000). [No title found]. Journal of Mathematics Teacher Education, 3(2), 125-153. https:/ / doi.org/10.1023/A:1009947032694

Brown, C. A., \& Borko, H. (1992). Becoming A Mathematics Teacher. In Grouws D.A. (Ed.). New York: NCTM.

Coocke, B. D., \& Buchholz, D. (2005). Mathematical Communication in the Classroom: A Teacher Makes a Difference. Early Childhood Education Journal, 32, No. 6.

Dahiana, W. O., Herman, T., \& Nirawati, R. (2020). Student Mathematical Communication Capability Improvement Using the Metacognitive Strategy. Volume 4, 194-197.

Demirel, M., Derman, I., \& Karagedik, E. (2015). A Study on the Relationship between Reflective Thinking Skills towards Problem Solving and Attitudes towards Mathematics. Procedia Social and Behavioral Sciences, 197, 2086-2096. https:// doi.org/10.1016/j.sbspro.2015.07.326

Fallan, L., \& Opstad, L. (2016). Student Self-Efficacy and Gender-Personality Interactions. 5 No.3. Fennema, E., \& Franke, M. L. (1992). Teachers"e knowledge and its impact. In D. A. Grouws (Ed.). New York: Macmillan., 147-164.

Fox, L. H., Brody, L., \& Tobin, D. (1980). Women and the mathematical mystique. Baltimore, MD: Johns Hopkins University Press. 
Gallagher, A. M., \& Frontmatter, J. C. K. (2005). Gender Differences in Mathematics An Integrative Psychological Approach. Cambridge University Press.

Goodwin, K. S., Ostrom, L., \& Scott, K. W. (2009). Gender Differences in Mathematics Self-Efficacy and Back Substitution in Multiple-Choice Assessment. 38, Number 1, p22-42.

Guiller, J., \& Durndell, A. (2007). Students' linguistic behavior in online discussion groups: Does gender matter? Computers in Human Behavior. www.elsevier.com/locate/comphumbeh

Hacker, D. J. (1998). Definitions and empirical foundations. In D. J. Hacker, J. Dunloky, \& A. C. Graesser (Eds.), Metacognition in educational theory and practice.

Hedges, L., \& Nowell, A. (1995). Sex differences in mental test scores, variability, and numbers of high-scoring individuals. Science, 269(5220), 41-45. https://doi.org/10.1126/science.7604277

Hendrian, H., Rohaeti, E. E., \& Sumarmo, U. (2018). Hard Skills dan Soft Skills Matematik Siswa. PT Refika Aditama.

Hyde, J. S., Fennema, E., \& Lamon, S. J. (1990). Gender differences in mathematics performance: A meta-analysis. Psychological Bulletin, 107(2), 139-155. https://doi.org/10.1037/00332909.107.2.139

Jbeili, I. (2012). The Effect of Cooperative Learning with Metacognitive Scaffolding on Mathematics Conceptual Understanding and Procedural Fluency. International journal for Research in Education (ijre).

Kimball, M. M. (1989). A new perspective on Women's Math achievement. 198-214.

Kramarski, B., \& Mizrach, N. (2006). Online Discussion and Self-Regulated Learning: Effects of Instructional Methods on Mathematical Literacy. Volume 99, 2006-Issue 4, 218-231.

Laurens, Th. (2014). Pengembangan Metakognisi Dalam Peningkatan Kualitas Pendidikan Matematika. Pidato Pengukuhan Guru Besar. Disampaikan pada Rapat Senat Tebuka Universitas Pattimura, 20 Nopember 2014.

Liliana, C., \& Lavinia, H. (2011). Gender Differences in Metacognitive Skills. A Study of the 8th Grade Pupils in Romania. Procedia - Social and Behavioral Sciences, 29, 396-401. https://doi.org/10.1016/j.sbspro.2011.11.255

Lindberg, S. M., Hyde, J. S., Petersen, J. L., \& Linn, M. C. (2010). New trends in gender and mathematics performance: A meta-analysis. Psychological Bulletin, 136(6), 1123-1135. https:// doi.org/10.1037/a0021276

Ma, X. (1999). Gender Differences in Growth in Mathematical Skills During Secondary Grades: A Growth Model Analysis. XLV, No. 4, Winter 1999,448-466.

Marzano, R. J., \& Association for Supervision and Curriculum Development (Ed.). (1988). Dimensions of thinking: A framework for curriculum and instruction. Association for Supervision and Curriculum Development.

Meggiolaro, S. (2018). Information and communication technologies use, gender and mathematics achievement: Evidence from Italy. Social Psychology of Education, 21(2), 497516. https://doi.org/10.1007/s11218-017-9425-7

NCTM. (2000). Princip and Standards for School Mathematics.

NCTM 1991.pdf. (t.t.).

Nerru, P. M., Mariani, S., \& Cahyono, E. (2013). Pembelajaran Metode Reciprocal Teaching Berbantuan Cabri Untuk Meningkatkan Komunikasi Matematik Siswa Kelas X. Vol 2 No 1. https://journal.unnes.ac.id/sju/index.php/ujmer/article/view/1238 
Ormrod, J. E. (2008). Psikologi Pendidikan Membantu Siswa Tumbuh dan Berkembang Jilid 1. Erlangga.

Pasaribu, I., Siagian, P., \& Amry, Z. (2018). The Differentiation of Improved Communication Mathematic and Disposition Skill Through Problem Based Learning and Realistic Mathematication Education. Proceedings of the 3rd Annual International Seminar on Transformative Education and Educational Leadership (AISTEEL 2018). Proceedings of the 3rd Annual International Seminar on Transformative Education and Educational Leadership (AISTEEL 2018), Medan, Indonesia. https://doi.org/10.2991/aisteel18.2018.16

Peterson, P., \& Fennema, E. (1985). Effective Teaching, Student Engagement in Classroom Activities, and Sex-Related Differences in Learning Mathematics. American Educational Research Journal, v22 n3, p309-35.

Ramdani, Y. (2012). Pengembangan Instrumen Dan Bahan Ajar Untuk Meningkatkan Kemampuan Komunikasi, Penalaran, Dan Koneksi Matematis Dalam Konsep Integral. 13(1), 9.

Randhawa, B. S. (1994). Self-efficacy in mathematics, attitudes, and achievement of boys and girls from restricted samples in two countries. Perceptual and Motor Skills.

Ruseffendi, E. T. (1993). Statistika Dasar untuk Penelitian Pendidikan. Departemen Pendidikan dan Kebudayaan Direktorat Jenderal Pendidikan Tinggi. Proyek Pembinaan Tenaga Kependidikan Pendidikan Tinggi. Buku Ajar Dosen MIPA LPTK.

Santos, L., \& Semana, S. (2015). Developing mathematics written communication through expository writing supported by assessment strategies. Educational Studies in Mathematics, 88(1), 65-87. https:/ / doi.org/10.1007/s10649-014-9557-z

Schoenfeld_1992 Learning to Think Mathematically.pdf. (t.t.).

Sefiany, M., Masrukan, \& Zaenuri. (2016). Kemampuan Komunikasi Matematis Siswa Kelas VII pada Pembelajaran Matematika dengan Model Knisley Berdasarkan Self Efficacy. Unnes Journal of Mathematics Education, 227-233.

Setati, M. (2002). Researching Mathematics Education and Language in Multilingual South Africa. $12(2), 15$.

Setiawan, E. (2013). Modernisasi Pola Sistem Pendidikan Pesantren (Studi Kasus Pondok Pesantren Modern Daarul Fikri Mulyoagung Dau Malang). ULUL ALBAB Jurnal Studi Islam, 14(2), 176. https:/ / doi.org/10.18860/ua.v14i2.2656

Sholihah, U. (2016). Membangun Metakognisi Siswa Dalam Memecahkan Masalah Matematika. 4 No $1,83-100$.

Steinbring, H. (2009). The construction of new mathematical knowledge in classroom interaction: An epistemological perspective. Springer.

Su, H. F. H. "Angie," Ricci, F. A., \& Mnatsakanian, M. (2016). Mathematical Teaching Strategies: Pathways to Critical Thinking and Metacognition. International Journal of Research in Education and Science, 2(1), 190. https:/ / doi.org/10.21890/ijres.57796

Tandililing, E. (2011). The Enhancement of Mathematical Communication and Self Regulated Learning of Senior High School Students Through PQ4R Strategy Accompanied by Refutation Text Reading. 12.

Veenman, M. V. J., Wilhelm, P., \& Beishuizen, J. J. (2004). The relation between intellectual and metacognitive skills from a developmental perspective. Learning and Instruction, 14(1), 89-109. https:/ / doi.org/10.1016/j.learninstruc.2003.10.004 
Wigfield, A., Battle, A., Keller, L. B., \& S. Eccles, J. (2002). Sex Differences in Motivation, SelfConcept, Career Aspiration and Career Choice: Implications for Cognitive Development. Greenwich CT: Ablex.

Woolfolk, A. (2007). Educational Psychology (Tenth Edition). New York, NY: Pearson Educational, Inc.

Zakiri, I. K., \& Pujiastuti, E. (2018). The mathematical communication ability based on gender difference on students of XI grade by using problem based learning model assisted by probing prompting technique. 7(2), 7.

Zakiri, I. K., Pujiastuti, E., \& Tri Sri Noor, A. (2018). The mathematical communication ability based on gender difference on students of XI grade by using problem based learning model assisted by probing prompting technique. Unnes Journal of Mathematics Education, 78-84. 